\title{
The present status of organ preservation: a review
}

\author{
G. L. MouZAS \\ M.D. \\ Department of Surgery, Yale University, \\ New Haven, Connecticut
}

IN THE LAST DECADE there has been some advancement in the field of organ transplantation, but organ preservation remains in the embryonic stage. The necessity for a simple and efficient method for organ preservation is becoming increasingly important.

In 1951, Dempster said, 'If the immunological problems, and other problems involved in procuring a normal functioning organ were solved our difficulties would be by no means over'.

While there is no difficulty in preserving skin and blood vessels in the frozen state, other organs require more delicate handling. Many research workers in this field are aiming at the possibility of setting up organ banks, but this wishful thought remains still a distant goal. Storage of organs up to 24-48 hr (especially of the kidney) has been attempted, but there is not yet a reliable simple method for use in clinical practice.

\section{History}

Some research workers correlate organ preservation with the fact that hibernating animals (hamster, squirrel, etc.) are capable of storing themselves satisfactorily at low temperatures without impairment of function. However, this correlation may be insignificant as an organ becomes ischaemic after the blood vessels are severed, a factor which may contribute to the unsuccessful experimental results in preservation of organs.

Different methods of storage have been attempted, e.g. perfusion, hypothermia and hyperbaric oxygen, or various combinations of the above.

LeGallois (1812), a French physiologist, wrote very evasively regarding the possibility of perfusing a vital organ, but he made no attempt to practice his ideas experimentally due to the lack of knowledge regarding a suitable perfusate. Carrel \& Lindberg (1938) reviewed the historical points of organ preservation very clearly and mentioned the work of Lobell who first perfused a kidney in 1849 .
Towards the end of the last century and at the beginning of this century, unsuccessful attempts were made to develop an apparatus to perfuse vital organs. In 1938, Carrel \& Lindberg developed a pulsatile pump carrying an oxygenated perfusate. The first organ preserved in vitro in their machine was the thyroid gland, but they failed to preserve kidneys; Carrel observed that the kidneys developed severe cellular damage within $24 \mathrm{hr}$, while being perfused in vitro.

With the advancement of medical science in the last two decades, organ preservation remained obscure until the work of Dubost et al. $(1951 \mathrm{a}, \mathrm{b})$ in Paris, Dempster (1950) in London and Hume et al. (1952) in the United States, in the field of kidney transplantation, stimulated other investigators to experiment in this field. Recently, with the advancement of cardiovascular research and the development of heart-lung machines, some workers have attempted to correlate this with organ preservation.

\section{Preservation of kidneys}

It has been observed that at room temperature, if the total ischaemic period is less than $1 \mathrm{hr}$, then adequate renal function is to be expected immediately after transplantation with only temporary abnormalities. If the period of ischaemia is between 1 and $2 \mathrm{hr}$, a varying degree of tubular necrosis occurs in the preserved kidney. Beyond $3 \mathrm{hr}$ of preservation there is irreversible damage and the kidney may never function sufficiently well to maintain life (Murray \& Holden, 1954).

\section{(a) Hypothermia}

Carrel \& Lindberg (1938) reported that after storage at $-1^{\circ} \mathrm{C}$ to $7^{\circ} \mathrm{C}$ the kidney ceased to function.

Lefebre \& Nizet (1952) and Archibal \& Cawley (1956) attempted to apply hypothermia in vitro to kidneys at $4^{\circ} \mathrm{C}$ up to $24 \mathrm{hr}$ but medullary necrosis resulted. 
Schloerb et al. (1957) reported successful 8-hr preservation at $0-5^{\circ} \mathrm{C}$ of canine kidneys. Murray \& Holden (1954) observed that the kidney survived and regained function after $2 \frac{1}{2} \mathrm{hr}$ storage at room temperature. On cooling from 10 to $40^{\circ} \mathrm{C}$, however, there was a longer interval during which it could be deprived of its blood supply without necrosis.

The author successfully preserved canine autografts by a simple cooling method at $4^{\circ} \mathrm{C}$ temperature up to $9 \mathrm{hr}$ with $80 \%$ success, but failed at 12 and $24 \mathrm{hr}$.

Calne (1963), Cleveland et al. (1964), Dempster et al. (1964) and Kiser et al. (1960), all reported successful kidney storage for 6-12 hr.

Simple cooling has been produced by surrounding the organ with ice packs or ice-cold saline in plastic containers. Cooling of an organ to $25^{\circ} \mathrm{C}$ produces no more than minimal improvement (Mitchell \& Woodruff, 1957; Moyer et al., 1957). At $15-25^{\circ} \mathrm{C}$ the improvement is more beneficial, $2 \mathrm{hr}$ ischaemia being readily tolerated (Bogardus \& Schlosser, 1956; Dottori et al., 1962).

However, when the temperature range between 5 and $15^{\circ} \mathrm{C}$ is reached, the preserved kidney improves significantly (Stueber et al., 1958). During cooling of the kidney, oxygen consumption decreases exponentially with falling temperature as reported by (Semb et al., 1960) reaching less than $5 \%$ of normal at $5^{\circ} \mathrm{C}$ (Levy, 1959).

(b) Hypothermia and perfusion

Lapchinsky (1960) reported successful preservation of organs, particularly kidneys. He pumped cold blood through a kidney for $1 \mathrm{hr}$ and stored it at $2-4^{\circ} \mathrm{C}$. Prior to transplantation warm blood was perfused. He reported successful storage for 24-48 hr. He reported successful survival of some experimental dogs after contralateral nephrectomy, using a special refrigerated machine for this perfusion-cooling method.

Humphries et al. (1962) perfused a kidney with diluted homologous blood at very low pressure $(40 \mathrm{mmHg})$, slightly pulsatile, oxygenated by a Clowes'-type membrane at $10^{\circ} \mathrm{C}$, and were able to prolong kidney preservation up to $24 \mathrm{hr}$.

Aird (1953) and Humphries et al. (1963) reported decreased blood flow in the preserved organ, and organ oedema during the 24 -hr perfusion of an isolated organ. Kiser et al. (1960) used a blood-dextran perfusion method to obtain a renal temperature of $1-5^{\circ} \mathrm{C}$ and satisfactory function resulted after $7 \mathrm{hr}$ ischaemia. Recently, Calne (1965) reported successful storage of canine kidneys for $24 \mathrm{hr}$ using cold blood to lower renal core temperature before refrigeration.

\section{(c) Super-cooling}

Deshpande et al. (1963) using sub-zero temperature $-6-8^{\circ} \mathrm{C}$ reported successful kidney storage up to $7 \mathrm{hr}$.

This is accomplished by using protective agents such as dimethylsulphoxide (DMSO) and glycerol. The above agents are chemical compounds which penetrate the cell membrane readily, they are non-toxic and bind intracellular water by forming very firm hydrogen bonds. At $-5^{\circ} \mathrm{C}$ DMSO interferes with the passage of intracellular water to the extracellular space. This prevents the formation of extracellular ice crystals and prevents freezing and its subsequent damage of the cells. Bloch et al. (1963) have studied in detail the use of DMSO and glycerol in super-cooling methods.

(d) Hyperbaric oxygen

As perfusion has proved to be inadequate in the preservation of kidneys, and the time factor a hazard in the use of hypothermia, hyperbaric oxygen was next introduced as another means of extending the preservation time. Saltzman et al. (1965) in a monograph reviewed the historical background of hyperbaric environment from the earlier days until the more recent advances in this field.

During the last decade, much work has been done by several investigators on the biological responses after increased atmospheric pressure and high tension of oxygen in animal and man. Borema (Borema et al., 1960) reported his famous experiment 'Life without Blood', using the pig and was able to sustain life without haemoglobin for $45 \mathrm{~min}$ at $3 \mathrm{~atm}$ high oxygen tension. Since the work of Borema, a new era started in this field but it remains in the experimental stages. Carrel (Carrel \& Lindberg, 1938) considered the potentials of hyperbaric environment in organ storage, reviewed later on by Woodruff (1960). Recently, Manax and his co-workers (1964) preserved kidneys up to $24 \mathrm{hr}$ and occasionally $48 \mathrm{hr}$ using hyperbaric oxygen and hypothermia. On increasing the pressure of oxygen to 8-15 atm, it was found to be more detrimental than beneficial in preserving the kidney.

Many research workers are now using various combinations of hypothermia, hyperbaric oxygen and perfusion.

Ackerman \& Barnard (1966) gave an excellent account of successful storage of kidneys by using a combination of the existing methods of hypothermia and hyperbaric oxygen at $3 \mathrm{~atm}$, and low pressure perfusion.

\section{Preservation of small intestines}

Cooling of the small intestine by lowering the temperature up to $24 \mathrm{hr}$ was unsuccessful (Eyal 
et al., 1965). Lillehei and his co-workers (1964) successfully preserved canine small intestine up to $24 \mathrm{hr}$ using hypothermia, $2^{\circ} \mathrm{C}$ and $3 \mathrm{~atm}$ of hyperbaric oxygen. Other research workers have been able to preserve small intestine up to $24 \mathrm{hr}$ using hyperbaric oxygen (Mandel \& Rudolf, 1966).

\section{Other organs}

Preservation of lungs, heart and liver is in the early experimental stages in many research departments but to date no significant progress has been reported.

The best method of organ preservation is still debatable, and some investigators have successfully preserved an organ for a reasonable time without using any complicated methods. A new approach to the problems involved is indicated, and a closer collaboration is called for between research workers in the field of transplantation, biologists and physiologists. The need for more comparative statistical research is necessary to establish the advantageous factors, and eliminate the methods which are not practicable in clinical work.

The work of preservation is quite correctly directed to autografts, but as yet we have no results of preservation in homografts, or evidence of the behaviour of an homograft after transplantation. It may be that in the experimental stages of preserving homografts, valuable information will be determined in solving this major problem.

\section{Summary}

A review of organ preservation has been made with special reference to the preservation of kidneys.

\section{References}

AckermanN, J.R.W. \& Barnard, C.N. (1966) Successful storage of kidneys. Brit. J. Surg. 53, 525.

AIRD, I. (1953) A mechanical heart-lung for use in man: Foreword to D. G. Melrose paper. Brit. med. J. ii, 57.

Archibal, D.J. \& CAWLEY, A.T. (1956) Some observations on transplantation of canine kidneys. Amer. J. vet. Res. $17,376$.

Bloch, J.H., Longerbeam, J.K., Manax, W.G. \& Lillehei, R.C. (1963) Preservative solutions for freezing organs in vitro. Trans. Amer. Soc. artif. intern. Org. 9, 139.

Bogardus, G.M. \& Schlosser, R.J. (1956) Influence of temperature upon ischemic renal damage. Surgery, 39, 970.

Borema, I., Meyne, N.G., Blummelkamp, W.K., Bouma, S., Mensch, M.H., Kamermas, F., Hauf, M.S. \& Alderen, W.V. (1960) Life without blood. J. cardiac Surg. 1, 33 .

CALNE, R.Y. (1963) Renal Transplantation. Arnold, London. CALne, R.Y. (1965) Supply and preservation of kidneys. Brit. med. J. i, 166.

Calne, R.Y., Pegg, D.E., Pryde-Davies, J. \& Brown, F.L. (1963) Renal preservation by ice cooling. Brit. med. J. ii, 651.
Carrel, A. \& Lindberg, C.A. (1938) The Culture of Organs. Hamilton, London.

Cleveland, R.J., Lee, H.M., Prout, G.R. \& Hume, D.M. (1964) Preservation of the cadaver kidney for renal homotransplantation in man. Surg. Gynec. Obstet. 119, 991.

DEMPSTER, W.J. (1950) Observations on the behaviour of the transplanted kidney in dogs. Ann. roy. Coll. Surg. 7, 275.

Dempster, W.J. (1951) Problems involved in the homotransplantation of tissues with particular reference to skin. Brit. med. J. ii, 1041.

Dempster, W.J., Kountz, S.L. \& Jovanovic, M. (1964) Simple kidney storage technique. Brit. med. J. i, 407.

Deshpande, P.J. \& JACOB, S.W. (1963) Successful storage of kidneys at sub-zero temperatures. Surg. Forum, 14, 176.

Dottori, O., Ekestrom, S. \& Hansson, L.O. (1962) Local cooling of the kidney using perfusion technique. Acta chir. scand. 124, 80.

Dubost, C., Oeconomos, N., Vaysse, J., Hamburger, J., Nenna, A. \& Milliez, P. (1950) Resultates di une tentative greffe renale. Bull. Mem. Soc. méd. Hop. Paris, 67, 1372.

Dubost, C., Oecomonos, N., Vaysse, J., Hamburger, J., Milliez, P. \& LeCrigand, J. (1951) Note preliminaire sur l'étude des fonctions renales de reins greffes chez l' homme. Bull. Mem. Soc. méd. Hop. Paris, 67, 105.

Eyal, J., Manax, W.G., Bloch, J.H. \& Lillehei, R.C. (1965) Successful in vitro storage of small bowel, including maintenance of mucosal integrity with chlorpromazine, hypothermia and hyperbaric oxygen. Surgery, 57, 259.

Humphries, A.L., Ostafin, R.R., Goodrich, S.M. \& MORETZ, W.H. (1962) Successful reimplantation of dog kidney after 24 hour storage. Surg. Forum, 13, 380.

Humphries, A.L., Russell, R., Ostofin, J., Goodrich, S.M. \& MORETZ, W.H. (1963) Successful reimplantation of canine kidney after 24 hour storage. Surgery, 54, 136.

Hume, D.M., Merrill, J.P. \& Miller, B.F. (1952) Homologous transplantation of human kidneys. J. clin. Invest. $31,640$.

Kiser, J.C., Farley, H.H., Mueller, G.F., Strobel, C.J. \& Hiтchсоск, C.R. (1960) Successful renal autografts in the dog after seven hour selective kidney refrigeration. Surg. Forum, 11, 26.

Kiser, J.C., Telander, R.L., Peterson, T.A., Coe, J.I. \& Hıтснсоск, C.R. (1961) Canine renal autografts. Arch. Surg. 83, 502 .

LAPCHINSKY, A.G. (1960) Recent results of experimental transplantation of preserved limbs and kidney and possible use of this technique in clinical practice. Ann. N. Y. Acad. Sci. 87, 539.

Le Gallois, C.J.J. (1812) Experiences sur le Principle de la Vie. D'Hautel, Paris.

Levy, M.N. (1959) Oxygen consumption and blood flow in the hypothermic perfused kidney. Amer. J. Physiol. 197, 1111 .

Lefebre, L. \& Nizet, E. (1952) Shunt vasculaire dans les reins de chien perfusés et conservés a basse temperature. Arch. intern. Pharmacodyn. 92, (1849) 119.

Lillehei, R.C., Manax, W.G., Bloch, J.H., Hildago, F. \& LONGERBEAM, J.K. (1964) In vitro preservation of whole organs by hypothermia and hyperbaric oxygen. J. Cardiol. 1,181 .

Lobell, J. (1849) (Reported by A. Carrel 1938) Carrel, A. $\&$ LiNDBERG, C.A. (1938) The Culture of Organs. Hoeber, New York.

ManaX, W.C., Bloch, J.H., Longerbeam, J.K. \& Lillehei, R.C. (1964) Successful 24 hour in vitro preservation of canine kidneys by the combined use of hyperbaric oxygenation and hypothermia. Surgery, 56, 275. 
Mitchell, R.M. \& Woodruff, M.F.A. (1957) The effect of local hypothermia in increasing tolerance of the kidney to ischemia. Transplant. Bull. 4, 15.

Moyer, J.H., Heider, C., Morris, G.C.J. \& Handley, C. (1957) Hypothermia III. The effect of hypothermia on renal damage resulting from ischemia. Ann. Surg. 146, 152 (1954).

Murray, G.D.W. \& Holden, R. (1954) Transplantation of kidneys experimentally and in human cases. Amer. $J$. Surg. 87, 508.

MANDEL, S. \& Rudolf, L.E. (1966) Organ preservation. Trans. Amer. Soc. artif. intern. Org. 12, 229.
Schloerb, P.R., Waldorf, R.D. \& Welsh, J.S. (1957) The protective effect of kidney hypothermia on total renal ischemia. Surg. Forum, 8, 633.

Saltzman, H.A., Smith, W.W., Fuson, R.L., Sieker, H.O. \& Brown, I.W. (1965) Hyperbaric oxygen homografts. Surg. Sci. 2, 1.

Semb, G., Krog, J. \& Johansen, K. (1960) Renal metabolism and blood flow during local hypothermia, studied by means of renal perfusion in situ. Acta chir. scand. Suppl. No. 253, 196.

Stueber, P., Kovacs, S., Koletsky, S. \& Persky, L. (1958) Regional renal hypothermia. Surgery, 44, 77.

WoODRUfF, M.F.A. (1960) The Transplantation of Tissues and organs. Thomas, Springfield, Illinois. 